\title{
TEKNIK GURU PENDIDIKAN AGAMA HINDU DALAM MENCIPTAKAN PEMBELAJARAN BERBASIS PAIKEM DI SMP NEGERI 2 WLINGI-BLITAR, JAWA TIMUR
}

\author{
Oleh: \\ Sujianto \\ Fakultas Pendidikan Agama dan Seni \\ Universitas Hindu Indonesia, Denpasar \\ jiant.unhidps@gmail.com
}

\begin{abstract}
PAIKEM-based learning is one of learning designs based on the constructivistic approach. Learning is a process of manifestion of ideas into new experiences. Knowledge is built little by little and the results are expanded through an unlimited context and cannot be constructed abruptly. In the constructivist view, the strategy of gaining knowledge is more precedence over than how many the students remember the knowledge. While the role of the teachers during the learning process is as only as the facilitator who facilitates student in learning by making meaningful and relevant knowledge, giving the students the opportunity to find and apply ideas and awaken the students to apply their strategies during the learning process.
\end{abstract}

Keywords: Constructivistic, active learning, PAIKEM

\begin{abstract}
Abstrak
Pembelajaran berbasis PAIKEM merupakan salah satu desain pembelajaran berdasarkan pendekatan konstruktivistik. Belajar merupakan proses penuangan ide-ide ke dalam pengalaman baru. Pengetahuan dibangun sedikit demi sedikit dan hasilnya diperluas melalui konteks yang tidak terbatas dan tidak tidak dengan tiba-tiba. Menurut pandangan konstruktivistik, strategi memperoleh lebih diutamakan dibandingkan dengan seberapa banyak siswa mengingat pengetahuan. Sedangkan peran guru selama proses pembelajaran adalah sebagai fasilitator yang memfasilitasi pembelajaran siswa dengan cara menjadikan pengetahuan bermakna dan relevan bagi siswa, memberikan kesempatan kepada siswa untuk menemukan dan menerapkan ide-ide dan menyadarkan siswa agar menerapkan strategi mereka dalam belajar.
\end{abstract}

Kata kunci: konstruktivistik, pembelajaran aktif, PAIKEM

\section{PENDAHULUAN}

Dunia pendidikan adalah dunia yang amat komplek, menantang dan mulia. Komplek, karena spektrumnya sangat luas, menantang, karena menentukan masa depan bangsa dan mulia karena memanusiakan manusia. Demikian catatan penting yang disampaikan Mohammad
Nuh, selaku menteri pendidikan nasional pada saat menyampaikan pidato Rembuk Nasional Pendidikan 2010, di kantor Pusat Pendidikan dan Pelatihan Kementerian Pendidikan Nasional (Yoggi, dalam Majalah Kampus No.5/vol.1/Juni 2010: 21).

Mohammad Nuh menambahkan, pendidikan ibarat seorang ibu hamil yang akan melahirkan 
generasi baru. Dalam kondisi yang normal, kelahiran sang bayi bukan saja membahagiakan tetapi juga sangat dinantikan. Namun bila kondisi kesehatan sang ibu mengkhawatirkan, psikisnya labil dan tertekan, asupan gizi yang tidak mencukupi, hal ini tentu tidak saja merisaukan terhadap keadaan ibu, tetapi juga sangat merisaukan terhadap kesehatan dan kualitas sang bayi yang akan dilahirkan. Bisa jadi akan lahir generasi yang tidak memiliki kemampuan untuk mandiri, kepekaan dan ketajaman sosial serta selalu asyik sendiri dengan dunianya. Atas dasar inilah maka sesungguhnya hubungan antara kualitas Sumber Daya Manusia (SDM) dengan kualitas pendidikan sangat jelas sekali.

Pemikiran-pemikiran Mohammad Nuh di atas secara implisit sangat menyentuh dengan keadaan dunia pendidikan Nasional. Muslim (2009: 2), sebagai bahan pemikiran kualitas Sumber Daya Manusia (SDM) Indonesia, dapat diperhatikan dan dicermati data Human Development Index (HDI) tentang mutu pendidikan Indonesia. Berdasarkan survey yang dilakukan oleh United Nations Human Development Report (UNHDR) di tingkat ASEAN pada tahun 2010, Indonesia berada pada ranking 108 dari 169 negera yang disurvey. Mutu pendidikan Indonesia masih tertinggal jauh dengan negara-negara berkembang lainya seperti Singapura, Brunei, Malaysia, Thailand dan Filipina (UNHDR, download pada 27 Mei 2011).

Rendahnya mutu pendidikan Nasional, menurut Habbie (dalam Ruindungan, 1996:8) dari hasil penelitiannya menyatakan bahwa, sistem pendidikan Indonesia masih belum mampu memberikan ruang yang lebih luas bagi pengembangan kemampuan kreatif, khususnya kreatifitas berpikir anak. Munandar (1999: 12) mengatakan, pihak sekolah belum atau kurang merangsang kemampuan berpikir kreatif siswa.

Gejala di atas terjadi pula dalam implementasi kurikulum tingkat menengah pertama hampir di setiap mata pelajaran, baik dilihat dari makna kreatifitas sebagai produk, proses, pribadimaupun press. Sanusi (1998:226) menyatakan bahwa transfer informasi dalam pengajaran di sekolah hanya mencapai tujuan kognitif yang mengulit bawang dan ketinggalan jaman. Hasil belajar di sekolah hanya mempunyai relevansi dengan tujuan kurikulum formal yang terbatas dan tidak memiliki relevansi yang berarti dengan kehidupan kemasyarakatan yang nyata, bahkan terkesan membosankan dan tidak lagi disenangi siswa. Dalam proses pembelajaran belum terjadi adanya transfer konsep budaya berpikir cerdas, kritis dan sistematis.

Dalam rangka merenovasi paradigma tersebut, Standar Nasional Pendidikan mempertegas dalam PP Nomor 19 tahun 2005 bab I pasal 1 ayat (6) tentang standar Proses. Proses pembelajaran harus dilaksanakan secara inspiratif, menyenangkan, menantang, memotivasi peserta didik untuk berpartisipasi aktif, serta memberikan ruang yang cukup untuk mengembangkan krativitas dan kemandirian sesuai dengan bakat dan minat peserta didik (PP Nomor 19 bab IV pasal 19 ayat (1)).

Namun demikian, Standar Nasional Pendidikan tersebut belumlah optimal dilaksanakan di Indonesia. Idealnya dua tahun setelah UndangUndang tersebut resmi disahkan oleh negera, seharusnya seluruh instansi pendidikan telah mampu mengimplementasikannya. Namun kenyataan yang terjadi di lapangan masih banyak sekolah yang belum memahami apalagi menerapkan isi perundangan-udangan dalam Standar Nasional Pendidikan tersebut. Kondisi ini kemudian dikritik oleh berbagai kalangan mulai dari cendekiawan, ilmuwan sampai pada kalangan teknokrat yang ikut mengkhawatirkan keberadaaan mutu pendidikan di Indonesia (Suda, 2009:5).

Fenomena di atas sangatlah sulit untuk diselesaikan dengan segera. Sebaliknya, membiarkannya tanpa memberikan solusi penyelesaian merupakan tindakan yang tidak bijaksana. Oleh karena itu untuk mengatasi fenomena di atas, salah satu cara yang bisa dilakukan adalah melakukan pengkajian secara mendalam terhadap persoalan-persoalan tersebut berdasarkan rujukan filosofis atau teori valid dan penelitian (Sanusi, 1998:267). Hidayanto (1998:6) menyatakan bahwa, untuk meningkatkan relevansi belajar siswa dengan tujuan pembelajaran perlu dilakukan pengkajian terhadap struktur isi materi kurikulum dan perbaikan teknik, strategi dan metode selama proses pembelajaran.

Proses pembelajaran merupakan kata kunci yang harus dipegang erat-erat manakala ingin mewujudkan pendidikan nasional yang berkualitas, artinya proses memperoleh hasil lebih penting daripada hasil yang dicapai. Darmaningtyas (2007: 209-215) menyatakan, orientasi belajar yang terjadi sekarang ini lebih menguta- 
makan pada produk atau hasil akhir dan kurang memperhatikan proses. Padahal, proses mendapatkan ilmu pengetahuan jauh lebih berharga daripada produk pengetahuan itu sendiri. Orang Jawa mengatakan 'ilmu iku kelakone kanti laku' (pencapaian ilmu itu melalui proses belajar). Laku atau proses itu bisa dalam hitungan bulan, tetapi juga bisa dalam hitungan tahun. Substansi dari pesan itu adalah, tidak ada ilmu yang dapat dipetik serba instan tanpa melalui proses belajar.

Dengan paradigma pendidikan seperti itu, seharusnya tidak hanya dijadikan wacana oleh instansi pendidikan mengenai proses pembelajaran dalam rangka menghasilkan produk pembelajar yang berkualitas, tetapi harus dilaksanakan oleh seluruh instansi pendidikan dan praktisi pendidikan jika ingin menjadikan bangsa ini menjadi bangsa yang bermartabat di mata dunia dan terlahir sebagai negara yang bermoral dan berpendidikan. Darmaningtyas (2007: 214), institusi formal merupakan proses untuk mendapatkan ilmu pengetahuan, pendewassaan diri, pematangan pribadi, berkomunikasi, berorganisasi dan membangun relasi dengan sesama agar menjadi pribadi yang dewasa, berwawasan luas, berjiwa matang, tidak kuper, punya prinsip hidup yang kuat, memiliki integritas yang tinggi dan tidak plin-plan dalam mengambil keputusan. Sebagai proses dalam pembelajaran, ukuran keberhasilan bukan hanya produk akhir saja, tetapi juga terlaksananya proses pembelajaran itu dengan baik. Dengan kata lain, indikator yang perlu dilihat bukan hanya indikator hasil saja, tetapi juga indikator proses.

\section{PEMBAHASAN}

\subsection{Latar Belakang Penciptaan Pembela- jaran Berbasis PAIKEM}

Beberapa hal yang melatarbelakangi diciptakannya pembelajaran pendidikan agama Hindu berbasis PAIKEM di SMP Negeri 2 Wlingi-Blitar, Jawa Timur, antara lain:

Pertama, Tuntutan Kurikulum. Kurikulum merupakan seperangkat rencana dan pengaturan mengenai tujuan, isi dan bahan pelajaran serta cara yang digunakan sebagai pedoman penyelenggaraan kegiatan pembelajaran untuk mencapai tujuan pendidikan tertentu (UU Nomor 20 tahun 2003 tentang Sisdiknas, bab I pas- al 1 ayat (19)). Tujuan tertentu ini meliputi tujuan pendidikan nasional serta kesesuaian dengan kekhasan, kondisi dan potensi daerah, satuan pendidikan serta peserta didik (Muslich, 2007:3). Oleh sebab itu kurikulum disusun oleh satuan pendidikan untuk memungkinkan penyesuaian program pendidikan dengan kebutuhan dan potensi yang ada di daerah.

Pertengahan 2006 silam, sistem pendidikan Indonesia mengalami pergantian kurikulum dari yang awalnya menggunakan Kurikulum Berbasis Kompetensi (KBK) menjadi Kurikulum Tingkat Satuan Pendidikan (KTSP). Kurikulum Tingkat Satuan Pendidikan (KTSP) merupakan kurikulum operasional yang disusun oleh dan dilaksanakan di masing-masing satuan pendidikan (PP No.19 tahun 2005, pasal 1 ayat (15)).

Sesuai dengan rumusan di dalam Standar Isi pada Kurikulum Tingkat Satuan Pendidikan (KTSP) di dalamnya memuat kelompok mata pelajaran agama dan akhlak mulia. Relevansinya dengan judul skripsi dalam penelitian ini difokuskan pada mata pelajaran pendidikan agama Hindu, khususnya yang dilaksanakan di SMP Negeri 2 Wlingi-Blitar, Jawa Timur. Pendidikan agama Hindu merupakan suatu bentuk pembelajaran yang dibebankan untuk memberikan pengetahuan, sikap, kepribadian dan keterampilan kepada peserta didik (Suardeyasa, 2011:69). Pengetahuan sebagai pembelajaran untuk mengembangkan kognitif, sikap merupakan pengembangan aspek afektif (susila), kepribadian merupakan kekayaan batin (spiritual dan emosional), sedangkan pemberian keterampilan ditujukan untuk membentuk kecakapan kinestetik.

Itulah sebabnya, di dalam pembelajaran pendidikan agama Hindu dibutuhkan suatu bentuk inovasi pembelajaran yang mengarah pencapaian tujuan pembelajaran pendidikan agama Hin$\mathrm{du}$, yakni pembentukan mental, spiritual dan kepribadian seutuhnya yang mencakup pada ranah kognitif, psikomotor dan afektif. Pembelajaran pendidikan agama Hindu berbasis aktif, inovatif, kreatif, efektif dan menyenangkan (PAIKEM) merupakan solusi dalam rangka mencapai tujuan pembelajaran di dalam KTSP. Karena pada hal prinsip, KTSP memberikan keleluasaan kepada masing-masing instansi untuk membuat desain model pembelajaran dan PAIKEM merupakan alternatif untuk mewujudkan keberagaman model yang digunakan di masing-masing 
instansi menjadi sebuah kesamaan dalam proses pelaksanaannya. Dengan demikian, implementasi KTSP dalam pembelajaran pendidikan agama Hindu benar-benar mampu memberikan ruang gerak yang cukup luas kepada peserta didik untuk berkarya, berkreasi dan mengembangkan ide-idenya menjadi gagasan-gagasan baru sesuai dengan prinsip utamanya yaitu pembelajaran aktif, inovatif, kreatif, efektif dan menyenangkan (PAIKEM) selama proses pembelajaran berlangsung.

Kedua, PP No.19/2005 tentang Standar Nasional Pendidikan.Standar Nasional Pendidikan sebagai acuan dalam penyusunan Kurikulum Tingkat Satuan Pendidikan (KTSP) memberikan kontribusi yang sangat besar terhadap jalannya proses pembelajaran. Proses pembelajaran pada satuan pendidikan diselenggarakan secara interaktif, inspiratif, menyenangkan, menantang, memotivasi peserta didik untuk berpartisipasi aktif, serta memberikan ruang yang cukup bagi prakarsa, kreatifitas dan kemandirian sesuai dengan bakat, minat dan perkembangan fisik serta psikologis peserta didik (PP No.19/2005, bab IV pasal 19 ayat (1)).

Dalam rangka mengimplementasikan isi yang tertuang di dalam Peraturan Pemerintah tersebut, maka salah satu bentuk model pembelajaran yang sesuai adalah pembelajaran yang berbasis kompetensi. Pembelajaran berbasis kompetensi merupakan pembelajaran yang dilakukan dengan orientasi pencapaian kompetensi peserta didik (Direktorat Tenaga Kependidikan, 2010: 6). Sehingga muara akhir yang merupakan hasil dari pembelajaran adalah meningkatnya kompetensi peserta didik yang dapat diukur dalam pola, sikap, pengetahuan dan keterampilan. Salah satu bentuk inovasi baru dalam dunia pendidikan adalah pembelajaran berbasis aktif, inovatif, kreatif, efektif dan menyenangkan (PAIKEM).

Ketiga, Perubahan Paradigma dalam Pembelajaran.Salah satu prinsip yang paling penting dari psikologi pendidikan (Direktorat Tenaga Kependidikan, 2010:2) adalah guru tidak boleh semata-mata memberikan pengetahuan kepada siswa. Siswa harus membangun pengetahuan dalam benaknya sendiri. Guru dapat membantu proses ini dengan cara mengajar yang membuat informasi menjadi sangat bermakna dan sangat relevan bagi siswa, dengan memberikan ide-ide, dengan mengajak siswa agar menyadari dan menggunakan sendiri ide-ide tersebut dan mengajak siswa untuk menyadari dan menggunakan teknik-teknik mereka sendiri dalam belajar. Guru dapat memberikan kepada siswa tangga yang dapat membantu mereka mencapai tingkat pemahaman yang lebih tinggi, tetapi harus diupayakan siswa sendiri yang memanjat tangga itu.

Undang-Undang Nomor 20 tahun 2003 tentang Sistem Pendidikan Nasional (Sisdiknas) pasal 40 ayat 1 (a) menyatakan "guru dan tenaga kependidikan berkewajiban untuk menciptakan suasana pendidikan yang bermakna, menyenangkan, kreatif, dinamis dan dialogis" dan PP Nomor 19 tahun 2005 tentang Standar Nasional Pendidikan, bab IV pasal 19 ayat 1 menyatakan tentang penyelenggaraan proses pembelajaran pada satuan pendidikan agar dilaksanakan secara interaktif, inspiratif, menyenangkan, memotivasi siswa untuk berpartisipasi secara aktif dalam rangka mengembangkan kreatifitas dan kemandirian siswa sesuai dengan bakat, minat dan perkembangan fisik siswa.

Amanah dalam perundang-undangan tersebut memberikan asumsi dasar bahwa belajar itu diupayakan siswa sendiri yang membangun konsep selama terjadi proses pembelajaran, bukan gurunya yang membangun konsep. Belajar dalam konteks PAIKEM dimaknai sebagai proses aktif dalam membangun pengetahuan atau membangun makna. Proses membangun makna dilakukan secara terus menerus (sepanjang hayat). Memaknai sebuah pembelajaran dipengaruhi oleh pandangan konstruktivisme. Pandangan konstruktivisme menjelaskan bahwa di dalam proses belajar, manusia itu membangun pemahaman dan pengetahuannya mengenai dunia sekitarnya melalui pengenalan terhadap benda-benda di sekitarnya yang direfleksikan melalui pengalamannya. Wicaksono (2011:6), ketika manusia itu menemukan sesuatu yang baru, kemudian dikontruksinya dengan ide-ide awal dari pengalaman yang pernah dimilikinya, memungkinkan pengetahuan tersebut mengubah keyakinan awal yang telah dimilikinya atau bisa jadi merupakan informasi baru yang diabaikan karena merupakan sesuatu yang tidak relevan dengan ide awalnya.

\subsection{Proses Pembelajaran Pendidikan Agama Hindu Berbasis PAIKEM \\ Pertama, Kegiatan Tatap Muka.Yang dimak-}


sud dengan kegiatan tatap muka berdasarkan uraian dalam Permendiknas Nomor 22 tahun 2006 tentang Standar Isi adalah kegiatan pembelajaran yang berupa proses interaksi antara peserta didik dengan pendidik. Di dalam kegiatan tatap muka ini, guru mempunyai kedudukan sebagai fasilitator bagi siswa. Peran guru sebagai fasilitator dalam pembelajaran yaitu guru memberikan pelayanan untuk memudahkan siswa dalam kegiatan proses pembelajaran (Sanjaya, 2009: 23).

Pelayanan yang dimaksud adalah bagaimana tindakan yang harus dilakukan oleh guru agar siswa dapat dengan mudah melakukan dan mempelajari bahan-bahan pelajaran sehingga tujuan pembelajaran dapat tercapai secara optimal. Untuk mencapai tujuan tersebut, Guru pendidikan agama Hindu di SMP Negeri 2 WlingiBlitar, Jawa Timur menggunakan beberapa teknik pembelajaran selama kegiatan tatap muka, yaitu:

Menjelaskan tujuan belajar kepada peserta didik. Sebelum proses pembelajaran dimulai, guru menjelaskan mengenai tujuan pembelajaran yang akan dilaksanakan yang nantinya harus dicapai oleh siswa setelah proses pembelajaran usai. Veithzal dan Sylviana (2008: 457) memaparkan, semakin jelas tujuan instruksional yang dijelaskan oleh guru sebelum dimulainya pembelajaran, maka akan memberikan motivasi yang tinggi pula kepada siswa dalam mengikuti pembelajaran. Dalam menjelaskan tujuan belajar tersebut, guru menggunakan teknik atau cara dengan menuliskannya di papan tulis, sehingga secara tidak langsung perhatian siswa akan terfokus dengan apa yang telah dituliskan oleh guru. Hal ini juga merupakan sebuah teknik yang bisa dilakukan oleh guru dalam rangka memfokuskan perhatian siswa kepada suatu materi ajar.

Guru memberikan hadiah kepada murid yang berprestasi. Untuk memacu semangat belajar siswa, guru pendidikan agama Hindu di SMP Negeri 2 Wlingi-Blitar, Jawa Timur memberikan hadiah kepada siswanya yang memiliki prestasi. Selain memacu semangat siswa yang sudah berprestasi, pemberian hadiah juga akan dapat memacu siswa lain yang belum beprestasi (Veithzal dan Sylviana, 2008: 460). Pemberian hadiah ini tidak selamanya harus berupa benda, melainkan nilai/poin juga merupakan hadiah yang bisa diberikan oleh guru kepada siswa dalam rangka menumbuhkan semangat belajar siswa.

Guru memberikan dorongan belajar kepada peserta didik untuk belajar. Motivasi yang muncul dari dalam diri siswa memiliki pengaruh yang sangat besar terhadap minat dan semangat belajarnya. Namun demikian, dorongan yang berasal dari luar pun bukan berarti tidak memiliki arti. William Sternt (dalam Riyanto, 2010: 3) memaparkan teori belajar konvergensinya yang menyatakan bahwa perkembangan individu itu dipengaruhi oleh 2 faktor, yaitu faktor internal yang berasal dari dalam diri individu itu sendiri dan faktor eksternal yang berasal dari lingkungan dan orang-orang di sekitar individu tersebut berada.

Guru sebagai orang tua siswa ketika di sekolah juga mempunyai pengaruh dalam memberikan dorongan belajar kepada siswa. Veithzal dan Sylviana (2008: 465) memaparkan, dalam rangka membuat siswa menjadi lebih semangat dan giat lagi dalam belajar, maka guru dapat memberikan dorongan dengan cara memberikan perhatian yang maksimal kepada siswa pada saat pembelajaran, baik kepada siswa yang memiliki tingkat kecerdasan rendah, sedang maupun tinggi. Pemberian dorongan tersebut dapat dilakukan dengan cara melibatkan siswa secara aktif dalam kegiatan pembelajaran.

Kedua, Kegiatan Tugas Terstruktur.Kegiatan tugas terstruktur merupakan kegiatan pembelajaran yang berupa pendalaman materi untuk siswa yang mana dalam pelaksanaannya disusun dan dirancang oleh guru yang bersangkutan dalam rangka mencapai kompetensi yang telah ditetapkan (Permendiknas Nomor 22 tahun 2006). Kegiatan tugas terstruktur merupakan kegiatan pembelajaran yang mengembangkan kemandirian belajar peserta didik (Direktorat Tenaga Kependidikan, 2010:9). Dalam kegiatan tugas terstruktur ini, guru memiliki peran sebagai fasilitator, tutor dan teman belajar.

Implementasi tugas terstruktur mata pelajaran pendidikan agama Hindu yang dilaksanakan di SMP Negeri 2 Wlingi-Blitar, Jawa Tmur meliputi kegiatan pembelajaran sebagai berikut:

Pemberian tugas model portofolio. Tugas model portofolio merupakan salah satu bentuk alternatif evaluasi hasil belajar siswa yang dapat digunakan oleh guru untuk mengetahui kemampuan siswa dalam mengkonstruksi ilmu pengetahuan dan keterampilan yang dipelajarinya dengan menggunakan berbagai sumber belajar. 
Instrumen ini sangat diperlukan untuk menilai contoh kinerja atau performa siswa yang mencerminkan adanya pencapaian tujuan dalam pembelajaran (Benny, 2009: 175). Dengan kata lain, portofolio dapat diartikan sebagai hasil karya siswa yang diselesaikan dengan menggunakan berbagai sumber belajar untuk dapat mencapai tujuan pembelajaran yang telah ditetapkan di dalam Standar Kompetensi (SK) dan Kompetensi Dasar (KD).

Kegiatan pembelajaran kooperatif (cooperative learning). Kegiatan pembelajaran yang dilaksanakan secara kooperatif adalah siswa belajar dengan teman-temannya dalam satu kelompok belajar. Slavin (1995, dalam Sanjaya, 2009: 242) memaparkan, penggunaan pembelajaran secara kooperatif dapat meningkatkan prestasi belajar siswa sekaligus meningkatkan kemampuan siswa dalam hubungan sosial, serta dapat meningkatkan rasa percaya diri. Selain itu, pembelajaran secara kooperatif ini juga dapat merealisasikan kebutuhan siswa dalam berpikir, memecahkan masalah dan mengintegrasikan pengetahuan dengan keterampilan.

Ketiga, Kegiatan Mandiri Tidak Terstruktur. Sebagaimana yang diuraikan dalam Permendiknas Nomor 22 tahun 2006 tentang Standar Isi, yang dimaksud dengan Kegiatan Mandiri Tidak Terstruktur adalah kegiatan pembelajaran yang berupa pendalaman materi untuk siswa dalam rangka mengembangkan kemandirian belajar peserta didik. Di dalam struktur dan muatan kurikulum pada KTSP tentang pengaturan beban belajar, Kegiatan Mandiri Tidak Terstruktur ini dapat dilakukan dengan melaksanakan pembelajaran yang tidak tersusun secara rinci di dalam rencana pelaksanaan pembelajaran, silabus maupun isi kurikulum itu sendiri yang dilaksanakan sesuai dengan potensi dan kebutuhan siswa dalam mencapai kompetensi pada mata pelajaran tertentu (Muslich, 2007: 19).

Dalam mengimplementasikan Kegiatan pembelajaran Mandiri Tidak Terstruktur ini, guru dapat menggunakan strategi pembelajaran diskoveri inkuiri dengan melibatkan peran aktif dan kreatif siswa dalam mencari, menemukan, merancang dan menyusun sebuah pembelajaran (Direktorat Tenaga Kependidikan, 2010:9). Kegiatan pembelajaran Mandiri Tidak Terstruktur yang dilaksanakan di SMP Negeri 2 WlingiBlitar, Jawa Timur pada mata pelajaran pendidikan agama Hindu adalah kegiatan pembelajaran dalam bentuk pasraman. Pasraman merupakan satuan pendidikan keagamaan Hindu pada jalur pendidikan formal dan non formal (PP Nomor 55 tahun 2007, pasal 5).

Di dalam pelaksanaan pasraman ini, siswa akan diajari banyak hal yang berkaitan dengan agama Hindu, yang mana dalam pelaksanaan pembelajarannya tidak disusun atau ditetapkan di dalam rencana pelaksanaan pembelajaran, silabus maupun isi kurikulum di sekolah. Dengan demikian, pelaksanaan pasraman ini dimaksudkan untuk meningkatkan kemandirian dan kreatifitas siswa dalam mengimplementasikan konsepsi-konsepsi agama Hindu.

\subsection{Implikasi Pembelajaran Pendidikan Agama Hindu Berbasis PAIKEM}

Pertama, Implikasi terhadap Minat Belajar Siswa. Minat merupakan sesuatu yang sangat penting bagi seseorang untuk melakukan suatu aktivitas. Dengan minat orang akan berusaha mencapai suatu tujuan. Oleh karena itu minat dikatakan sebagai salah satu aspek psikis manusia yang dapat mendorong untuk mencapai tujuan yang diinginkan. Seseorang yang memiliki minat terhadap suatu obyek, akan cenderung untuk memperbaiki perhatian atau merasa senang yang lebih besar kepada obyek tersebut. Namun apabila obyek itu tidak menimbulkan rasa senang, maka ia tidak akan memiliki minat pada obyek itu sendiri. Menurut Hilgart (dalam Romlah, 2007: 22) minat adalah kecenderungan yang taat untuk memperhatikan dan mengenal beberapa kegiatan-kegiatan yang diminatidan diperhatikan oleh seseorang secara terus menerus yang disertai dengan perasaan dan rasa senang yang berlebihan.

Penciptaan iklim pembelajaran pendidikan agama Hindu berbasis PAIKEM dengan menggunakan teknik-teknik tertentu selama proses pembelajaran yang dilaksanakan oleh guru pendidikan agama Hindu di SMP Negeri 2 WlingiBlitar, Jawa Timur telah memberikan implikasi yang positif terhadap minat belajar siswa dalam mengikuti proses pembelajaran. Minat belajar yang tinggi ini terbukti dengan prosentase pencapaian ketuntasan minimal dalam belajar yang diraih oleh siswa. Pemberian motivasi untuk meningkatkan belajar siswa dalam mengikuti pelajaran pendidikan agama Hindu yang dilaksanakan oleh guru pendidikan agama Hindu di SMP Negeri 2 Wlingi-Blitar, Jawa Timur juga 
memberikan dampak yang cukup penting terhadap pembentukkan pribadi siswa.

Kedua, Implikasi terhadap Sikap dan Perilaku Siswa.Belajar merupakan proses perubahan tingkah laku. Namun demikian, proses terjadinya perubahan tingkah laku seseorang dalam belajar itu sulit untuk dilihat. Hal ini dikarenakan perubahan tingkah laku dalam belajar sangat berhubungan erat dengan perubahan sistem saraf dan perubahan energi yang sulit untuk dilihat maupun diraba. Oleh karena itu, terjadinya proses perubahan tingkah laku merupakan suatu misteri, hingga para ahli psikologi menamakannya sebagai kotak hitam (black box) (Sanjaya, 2009:57).Walaupun proses terjadinya perubahan tingkah laku pada diri setiap orang tidak dapat dilihat, sebenarnya dapat diamati apakah orang tersebut telah belajar atau belum dengan cara membandingkan kondisi sebelum dan sesudah proses pembelajaran berlangsung.

Sikap dan perilaku siswa yang tampak dari proses pembelajaran ini antara lain: Sopan santun siswa, nilai kesopanan memang tidak bisa diukur menggunakan angka, tetapi dapat diamati melalui perubahan tingkah laku yang terjadi pada seseorang. Kesopanan yang dapat diamati misalnya: dari caranya berpakaian, gaya bicara, sikapnya ketika berjumpa dengan guru dan sebagainya. Siswa memiliki rasa percaya di$r i$, rasa percaya diri itu perlu dimiliki oleh setiap orang dalam upaya pencapaian suatu tujuan atau cita-cita. Rasa percaya diri itu dapat ditumbuhkan mulai dari hal-hal yang kecil, misalnya percaya diri siswa pada saat mengerjakan ujian. Rasa percaya diri siswa ketika menyelesaikan soal ujian merupakan perilaku yang mencerminkan keyakinan terhadap dirinya bahwa mereka memang benar-benar sudah siap dalam menyelesaikan soal-soal ujian.

Menumbuhkan semangat kekeluargaan dan saling menolong. Pembelajaran berbasis PAIKEM, khususnya pada mata pelajaran pendidi- kan agama Hindu banyak memberikan peluang kepada guru maupun siswa dalam menjalin rasa kekeluargaan. Hal ini dikarenakan banyak hal yang bisa dilakukan oleh guru dan siswa serangkaian implementasi upacara maupun upakara agama. Misalnya, melaksanakan melasti, pawai ogoh-ogoh, mejejaitan, dharma santhi dan sebagainya. Kegiatan di atas secara tidak langsung akan menumbuhkan rasa kekeluargaan dan saling menolong diantara sesama.

\section{PENUTUP}

Pembelajaran pendidikan agama Hindu berbasis PAIKEM di SMP Negeri 2 Wlingi-Blitar, Jawa Timur dilaksanakan karena adanya perubahan paradigma dalam pembelajaran, yakni siswa "diajar" menjadi siswa "belajar" yang berlandaskan falsafah konstruktivisme. Paradigma tersebut lahir karena adanya amanah dalam PP No.19/2005 tentang Standar Nasional Pendidikan. Sedangkan Kurikulum Tingkat Satuan Pendidikan (KTSP) memberikan kontribusi terhadap pelaksanaan sistem pendidikan nasional dengan rambu-rambu pengimplementasiannya didasarkan pada BSNP. Di dalam KTSP inilah, kegiatan pembelajaran terdiri atas tiga poin penting, yakni kegiatan tatap muka, kegiatan terstruktur, dan kegiatan mandiri tidak terstruktur.

Penciptaan iklim pembelajaran berbasis PAIKEM pada mata pelajaran pendidikan agama Hindu di SMP Negeri 2 Wlingi-Blitar, Jawa Timur ini ternyata memberikan implikasi yang cukup positif terhadap minat belajar, sikap, perilaku siswa. Hal ini dapat dibuktikan dari prestasi belajar siswa, sopan santun siswa dan kepedulian siswa terhadap sesama. Dengan demikian, desain pembelajaran berbasis PAIKEM ini sangat perlu diterapkan oleh guru bidang studi pada mata pelajaran agama Hindu khususnya, dan bidang studi yang lain pada umunya. 


\section{DAFTAR PUSTAKA}

Benny, A. 2009. Model Desain Sistem Pembelajaran. Jakarta: Dian Rakyat.

Darmaningtyas. 2007. Pendidikan Rusak-Rusakan. Yogyakarta: LKiS.

Direktorat Tenaga Kependidikan. 2010. "Pembelajaran Berbasis PAIKEM (CTL, Pembelajaran Terpadu, Pembelajaran Tematik)". Makalah disajikan dalam rangka Pelatihan Penguatan Pengawas Sekolah di Jakarta. Jakarta, 20 Oktober 2010.

Hidayanto, D.N. 1998. Pengembangan Pembelajaran Menggunakan Komponen Display Theory (CDT) Model Implementasi pada Kurikulum Berbasis Kompetensi di SD. Disertasi pada PPS IKIP Bandung.

Munandar. 1999. Kreatifitas dan Keberbakatan: Strategi Mewujudkan Potensi Kreatif dan Bakat. Jakarta: PT. Gramedia Pustaka.

Muslim, Banun. 2009. Supervisi Pendidikan Meningkatkan Kualitas Profesionalisme Guru. Bandung: Alfabeta.

Muslich, Masnur. 2007. KTSP, Dasar dan Pemahaman. Jakarta: Bumi Aksara.

Peraturan Menteri Pendidikan Nasional Nomor 22 tahun 2006, tentang Standar Isi (SI), 2011. Jakarta (tidak diterbitkan).

Peraturan Pemerintah Indonesia Nomor 19 tahun 2005, tentang Standar Nasional Pendidikan (SNP), 2011. Jakarta (tidak diterbitkan).

Riyanto, Yatim. 2010. Paradigma Baru Pembelajaran, sebagai referensi bagi Pendidik dalam Implementasi Pembelajaran yang Efektif dan Berkualitas. Jakarta: Kencana Media Group.

Ruindungan, M.G. 1996. Model Bimbingan Peningkatan Kreatifitas Siswa SMU (Studi Kuasi Eksperimental Upaya Bantuan Pengembangan Berpikir Kreatif dan Sikap Kreatif pada siswa SMUK Dago Bandung. Disertasi pada PPS IKIP Bandung.

Sanusi, A. 1998. Pendidikan Alternatif: Menyentuh Arah Dasar Persoalan Pendidikan dan Kemasyarakatan. Bandung: PT. Grafindo Media Pratama.

Sanjaya, Wina. 2009. Strategi Pembelajaran, Berorientasi Standar Proses Pendidikan. Jakarta: Kencana Media Group.

Syah dan Kariadinata. 2009. "Bahan Pelatihan Pembelajaran Aktif, Inovatif, Kreatif, Efektif dan Menyenangkan (PAIKEM)”. Makalah disajikan dalam rangka Pendidikan dan Latihan Profesi Guru (PLPG), Rayon Fakultas Tarbiyah dan Keguruan UIN Sunan Gunung Djati Bandung tahun 2009.

Suda, I Ketut. 2009. Merkantilisme Pengetahuan dalam Bidang Pendidikan. Surabaya: Paramita.

Suardeyasa, IGN. 2011. Revitalisasi Pendidikan Agama Hindu berdasarkan PP No.55 tahun 2007. Dalam MEDIA HINDU, edisi Agustus 2011. Halaman 68-69.

Undang-Undang Nomor 20 tahun 2003, tentang Sistem Pendidikan Nasional, 2008. Bandung: Citra Umbara.

Veithzal dan Sylviana. 2008. Education Management, Analisis Teori dan Praktek. Jakarta: Rajawali Press.

Wicaksono, Andri. 2011. "Metode/Pendekatan Model Pembelajaran PAKEM (Pembelajaran Aktif, Kreatif, Efektif dan Menyenangkan)". Posting tanggal 4 Juni 2011, di download pada 28 Agustus 2011.

Yamin, Martinis. 2011. Paradigma Baru Pembelajaran. Jakarta: Gaung Persada Press.

Yoggi. 2010. "Paradigma Baru Pendidikan Tinggi Indonesia”. Dalam majalah KAMPUS, Nomor 5/ vol.1/Juni 2010. Halaman 20-23. 